\title{
Reproductive Performance and Fiber Quality Responses of Cotton to Potassium Nutrition
}

\author{
Suresh Lokhande, K. Raja Reddy* \\ Department of Plant and Soil Sciences, Mississippi State University, Mississippi State, MS, USA \\ Email: "krreddy@pss.msstate.edu
}

Received 12 March 2015; accepted 10 April 2015; published 14 April 2015

Copyright (C) 2015 by authors and Scientific Research Publishing Inc.

This work is licensed under the Creative Commons Attribution International License (CC BY). http://creativecommons.org/licenses/by/4.0/

(c) (i) Open Access

\begin{abstract}
Potassium (K) deficiency affects cotton growth and development and fiber properties. An experiment was conducted in an outdoor pot culture facility by imposing four potassium stress treatments $(100 \%, 40 \%, 20 \%$ and $0 \%$ of optimum $\mathrm{K}$ level) prior to flowering during 2010 and 2011 growing season. Upland cotton cultivar, TM-1, was seeded in the pots comprised of fine sand as rooting medium. Flowers and bolls were tagged daily to estimate boll maturation period (BMP). Leaf samples were collected every four days from flowering to maturity to estimate leaf $K$ content. Plant height and node numbers were recorded from emergence to 21 days after treatment. Photosynthesis and stomatal conductance were measured weekly from day of treatment imposition to physiological maturity at an interval of seven days. Stem, leaf, and boll dry-component weights, and boll numbers were recorded at the end of the experiment in each year. From each boll, the lint samples were collected and grouped based on average leaf potassium concentration during BMP, and fiber quality parameters were recorded for each group in each treatment. At high $\mathrm{K}$ deficient ( $0 \mathrm{~K}$ ) condition, total biomass declined by $27 \%$ and $28 \%$ in years 2010 and 2011 , respectively. Significantly, lower numbers of bolls were retained per plant at $0 \mathrm{~K}$ stress treatment during both the years. Leaf photosynthesis $\left(r^{2}=0.92\right)$ and stomatal conductance $\left(r^{2}=0.80\right)$ declined with declining leaf $\mathrm{K}$ levels. Fiber length, strength, micronaire, and uniformity declined linearly with decrease in leaf $K$ content. Weaker fibers with medium length were produced under K-deficient conditions with micronaire values in the discount range. Fiber uniformity, however, did not decline with decrease in leaf $K$. The identified leaf $K$ status-specific relationships for fiber properties could be used to improve management practices under potassium deficiency and to develop new sub-routines of the existing cotton simulation models. New and improved models will be useful not only in management, but also in arena of policy decisions including future climate change impact assessment analysis.
\end{abstract}

"Corresponding author.

How to cite this paper: Lokhande, S. and Reddy, K.R. (2015) Reproductive Performance and Fiber Quality Responses of Cotton to Potassium Nutrition. American Journal of Plant Sciences, 6, 911-924. http://dx.doi.org/10.4236/ajps.2015.67099 


\section{Keywords}

\section{Boll Maturation Period, Cotton, Growth, Development, Fiber Quality, Micronaire, Fiber Strength, Fiber Length, Fiber Uniformity, Photosynthesis, Stomatal Conductance, Potassium Nutrition}

\section{Introduction}

Cotton is one of the most economically important fiber crops and lint quantity and quality depend upon availability of nutrients and environmental conditions during growing season. Availability of major nutrients such as nitrogen, phosphorous and potassium $(\mathrm{K})$ plays an important role in cotton production [1] [2]. Being an important nutritional element, cotton growth, development is dependent on availability of $\mathrm{K}$ as it plays an important role in photosynthesis and accumulation and translocation of carbohydrates [3]. Potassium deficiency also influences senescence and physiological metabolism [4].

Potassium acts as osmoticum to balance the turgor pressure and regulate opening and closing of stomata [5] and balances the exchange of anions. It is a key element in enzyme activation [6] and physiological functions of the cells. It also influences the transportation of photoassimilates from leaves to other plant parts [7] and restricts fruit production to a greater extent [8]. As $\mathrm{K}$ is involved in carbohydrate translocation and transpiration, $\mathrm{K}$ deficiency substantially inhibits cotton vegetative and reproductive growth [9]. Potassium deficiency decreases photosynthesis via its impact on reducing leaf area, and reduction in stomatal conductance [10] [11], along with increasing mesophyll resistance. Therefore, it will be useful to study the relationships between K deficiency and various plant growth and developmental processes in cotton.

Several studies have focused on potassium nutrition effects on yield, and fruiting efficiency [9] [12]. These efforts were also extended to study effects on fiber quality [13] [14]. Potassium deficiency led to decreased leaf chlorophyll content and poor development of leaf anatomy [10]. As a result, there was a restriction on transport of photosynthate which led to accumulation of sugars in leaf tissues [15]. Potassium deficiency during the early blooming period decreased vegetative growth and plant biomass [16]. Only a small portion of total soil K is soluble and in an exchangeable forms readily available to plants [17]. Therefore, the peak blooming period in cotton has a strong association with nutrient uptake [12]. Potassium demand increases during boll development [18], particularly in recent high-fruiting and genetically-modified cultivars. As cotton plants produce bolls continuously, this stage of development is crucial for every study of the influence of K deficiency on seedcotton, seed and lint quantity and quality [14] [19]. Also, the timing and intensity of K stress are important factors in predicting its effect on fiber quality [20].

Fiber development initiates from the outer seed coat and undergoes the process of elongation and secondary wall deposition followed by maturation and drying [21]. Potassium is the key element in primary osmotica which increases turgor pressure during elongation of fiber which takes place from 0 to 20 days after anthesis [22], and thus K deficiency during this process decreases fiber length [23]. Apart from fiber length, the importance of micronaire and strength has increased relative to other parameters [24]. Studies carried out to evaluate K nutrition on eight cotton genotypes [9] reported a reduction in fiber length and micronaire. Fiber maturity is determined by the degree of secondary wall deposition, whereas micronaire is a measure of maturity and fineness. Ample supply of carbohydrates provided by canopy photosynthesis to growing bolls is linearly correlated with micronaire [25]. Cotton plants continuously produce bolls, so on a given day an individual boll may be at fiber elongation stage, while others may be in cell wall thickening or maturation phase [21] [22]. Therefore, the onset and intensity of K deficiency are very important to understand its effects on fiber development.

Although several studies have demonstrated the effect of K deficiency on vegetative growth and yield [26] [27], few studies have addressed the effect on lint quality [13] [14]. There is a demand for enhancing the overall profitability of cotton by optimizing lint quality without sacrificing the production quantity by using various improved agronomic practices. So, there is still an opportunity to improve direct cultural inputs during growing season to minimize effect of $\mathrm{K}$ stress on cotton reproductive performance and fiber properties. The objectives of this study were to evaluate the effects of potassium stress on cotton growth and reproductive performance and to study relationships between leaf potassium levels and fiber parameters. 


\section{Materials and Methods}

\subsection{Experimental Facilities}

The experiments were conducted in an out-door pot culture facility located at Environmental Plant Physiology Laboratory of the R. R. Foil Plant Science Research Center, Mississippi State University, Mississippi State, MS, USA $\left(33^{\circ} 28^{\prime} \mathrm{N}, 88^{\circ} 47^{\prime} \mathrm{W}\right)$ during the years of 2010 and 2011 . The pots were $0.65 \mathrm{~m}$ in height and $0.15 \mathrm{~m}$ in diameter with a small hole at the bottom to drain excess water. The study comprised of 320 pots with 80 pots per treatment and four replications of 20 pots each. The pots were oriented in east-west direction with 1-m spacing between rows. A drip irrigation system was laid out to irrigate the plants. The average temperatures during the treatment period were $27.2^{\circ} \mathrm{C}$ and $26.9^{\circ} \mathrm{C}$ in year 2010 and 2011 , respectively.

\subsection{Plant Culture and Potassium Treatments}

Four levels of potassium stress treatments of $100 \%, 40 \%, 20 \%$ and $0 \%$ of optimum K were imposed from flowering to crop maturity. Four different Hoagland's nutrient solution [28] of varied $\mathrm{K}$ in accordance with treatments were prepared, stored in different tanks, and pumped through plastic lines to respective plants by the drip irrigation system [3]. Prior to K stress treatments, all plants were well-watered with full-strength Hoagland's nutrient solution. Plants were irrigated three times a day to maintain optimum water supply throughout the experiment. Upland cotton (Gossypium hirsutum L.) cultivar Texas Marker (TM)-1, a genetic standard for many breeding and molecular studies [29] was seeded May 11 in 2010 and May 4 in 2011 in the pot facilities consisting of fine sand as growing medium similar to many experiments conducted in the facility [13]. Fifty percent of emergence was observed five days after seeding. Plants were harvested in each treatment when the plants reached over $80 \%$ of the harvestable bolls opened.

\subsection{Leaf Potassium Measurements}

In both years, three uppermost fully expanded leaves on mainstem from each $\mathrm{K}$ treatment were excised every 4 days from day of imposed treatment to physiological maturity. Leaf samples were dried at $70^{\circ} \mathrm{C}$ and for 72 hours and ground to pass 40 mesh screens. Leaf $\mathrm{K}$ was determined in the Soil Testing laboratory, Mississippi State University, according to the methods of [30] by using inductively coupled plasma optical emission spectroscopy and expressed in grams per kilogram of $\mathrm{K}$. As leaves were excised prior to analysis, the number of observation on given sampling dates were equivalent to number of treatments. The main focus leaf $\mathrm{K}$ analysis was to determine temporal changes in leaf potassium under different levels of nutrient stress and relate to reproductive performance and quality of lint produced in different fruiting zones, based on period of anthesis.

\subsection{Biomass and Yield Component Measurements}

Plant height from the cotyledonary node to the newest unfolded mainstem leaf was recorded from emergence to 25 days after potassium treatment at 5-day intervals. Similarly, the number of nodes on the mainstem was recorded at the same intervals. The plants were harvested when $80 \%$ of plants reached harvestable bolls opened. New flowers and open bolls were tagged daily throughout the experiment in all treatments. The day when the lint appears between the carpel walls is defined as open boll. Based on these dates, boll maturation period for each boll was estimated in all units [31]. The total number of bolls produced and mature (opened) bolls were recorded at the final harvest in all treatments. Stems, leaves, and reproductive structures were separated from each plant. Total biomass per plant was calculated by the adding dry weight of the different plant parts. Also, bolls were separated into burr, seed and lint and their respective weights were recorded.

\subsection{Gas Exchange Measurements}

Net photosynthetic rates and stomatal conductance of the uppermost, fully expanded leaves from four plants, one from each replication, in each treatment were measured between 10:00 and 13:00 h using LI-6400 (Li-COR Inc., Lincoln, Nebraska, USA) with an integrated fluorescence chamber head (LI-6400-40 leaf chamber fluorometer). The measurements were taken at $1500 \mu$ mole of photon $\cdot \mathrm{m}^{-2} \cdot \mathrm{s}^{-1}$ photosynthetically active radiation, cuvette air temperature set to $30^{\circ} \mathrm{C}$ and $\mathrm{CO}_{2}$ concentration was maintained at $380 \mu \mathrm{mol} \cdot \mathrm{mol}^{-1}$. Measurements were taken at $0,14,28,42$ and 56 days after treatment. 


\subsection{Chlorophyll Content and Cell Membrane Thermostability Measurements}

Leaf chlorophyll content in all potassium treatments were measured 42 DAT by taking one set of leaf samples collected from five fully expanded leaves for each treatment period. Five leaf discs, each with $2.0 \mathrm{~cm}^{2}$, from each sample were collected randomly and placed in vials containing $5 \mathrm{~mL}$ of dimethyl sulphoxide for chlorophyll (Chl) extraction. Absorbance of the extract was measured using a Bio-Rad ultraviolet/VIS spectrophotometer (Bio-Rad Laboratories, Hercules, CA, USA) at 470, 648, and $664 \mathrm{~nm}$ to calculate concentrations of Chla, Chlb, and carotenoid content [32] and expressed in $\mu \mathrm{g} \cdot \mathrm{cm}^{-2}$.

The leaf cell membrane thermostability (CMT) in potassium treatments was assessed on 42 DAT according to the procedure described by [33] with minor modification. In brief, a sample for assay consisted of a paired set namely; control (C) set and treatment (T) set, of five leaf disks each $1.3 \mathrm{~cm}^{2}$, cut from five fully expanded 3rd or 4th leaf from mainstem apex randomly selected leaves. Samples were replicated three times each. Prior to assay, the paired set of leaf disks were placed in two separate test tubes and washed thoroughly with four changes of deionized water, $10 \mathrm{~mL}$ each time, to remove electrolytes adhering to the cut surface of the leaf disks. After the final wash, both sets of test tubes were filled with $10 \mathrm{~mL}$ of deionized water and sealed with aluminum foil to minimize the evaporation of water. The T-set of the test tubes were incubated for 20 minutes at $50^{\circ} \mathrm{C}$ in a temperature controlled-water bath, whilst the C-set of test tubes were left at room temperature (approx. $25^{\circ} \mathrm{C}$ ). Then, both sets of test tubes were incubated at $10^{\circ} \mathrm{C}$ for $24 \mathrm{~h}$. Initial conductance readings of both sets (CEC1 and TEC1) using an electrical conductivity meter (Corning Checkmate II: Corning Inc., New York, NY, USA) were made after bringing test tubes to room temperature. After which, tubes were again sealed with aluminum foil and autoclaved at $120^{\circ} \mathrm{C}$ and $0.15 \mathrm{MPa}$ for $20 \mathrm{~min}$ to completely kill the leaf tissue. Autoclaved tubes were cooled to room temperature, contents mixed thoroughly and a final conductance (CEC2 and TEC2) was recorded. The CMT was calculated by using the following equation.

$$
\operatorname{CMT}(\%)=\frac{1-(\mathrm{TEC} 1 / \mathrm{TEC} 2)}{1-(\mathrm{CEC} 1 / \mathrm{CEC} 2)} \times 100
$$

where, TEC and CEC are the measure of conductance in treated and controlled test tubes, respectively, at initial $=1$ and final $=2$ conductance measurements.

\subsection{Fiber Quality Measurements}

In year 2011, for each potassium stress treatment, based on flowering dates, open bolls were divided into eight different groups. The bolls developed from the flowers that were produced in the first four days of flowering constituted the first group and similarly the rest groups of bolls were classified by successive interval of four days in each treatment. Overall from all potassium stress treatments, 32 groups were obtained. Average leaf K concentration for each group was estimated by running average of leaf $\mathrm{K}$ over boll maturation period for each group. All bolls from each group were analyzed for the fiber quality parameters. The lint samples were subjected for quality assessment by using High Volume Instrumentation (HVI) by the Fiber and Biopolymer Research Institute at Texas Tech University, Lubbock, TX as described by [34]. The HVI provides reports on five important quality characteristics describing the fiber length, strength, fineness, elongation, uniformity.

\subsection{Data Analysis}

The outside pot facility was designed identically in order to provide even growth conditions, with controlled potassium fertilization. Twenty plants per treatments were used for testing the significance of treatments, and standard errors of the mean are provided in the tables and figures. To test the significance of potassium stress on growth, dry matter and boll parameters were analyzed using general linear model PROC GLM in SAS and Fisher protected LSD tests at $P=0.05$ [35]. Regressions were fitted for leaf potassium content and fiber quality parameters from all treatments using SAS (SAS Institute Inc., 2011) and Sigma Plot 11.0 (Systat Software Inc., San Jose, CA, USA) to understand the relationships and to provide mathematical equations for fiber quality as a function of leaf $\mathrm{K}$.

\section{Results and Discussion}

\subsection{Leaf Potassium Content}

Monitoring and understanding of $\mathrm{K}$ requirement during crop growth are essential to study its effects and in 
making improved management decisions. Potassium concentration of uppermost fully expanded mainstem leaves differed among four levels of potassium treatments in the years, 2010 and 2011 (Figure 1). Symptoms of $\mathrm{K}$ deficiency including yellowing and premature leaf drop were observed in 20 and $0 \mathrm{~K}$ treatments predominantly in older leaves in both years. Whenever cotton leaf $\mathrm{K}$ concentration falls below $15 \mathrm{~g} \cdot \mathrm{kg}^{-1}$ during early bloom, the plant becomes deficient in $\mathrm{K}$ [16]. The $20 \mathrm{~K}$ treatment resulted in lowered leaf $\mathrm{K}, 11$ and $11.5 \mathrm{~g} \cdot \mathrm{kg}^{-1}$ in years 2010 and 2011, respectively (Figure 1). The severe $\mathrm{K}$ stress treatment, $0 \mathrm{~K}$, resulted in leaf $\mathrm{K}$ concentration dropping below $5 \mathrm{~g} \cdot \mathrm{kg}^{-1}$ at 60 days after treatment in both years of experiment, whereas in the control and $40 \mathrm{~K}$ treatments, the concentration of $\mathrm{K}$ in the leaves was above critical level and no visual $\mathrm{K}$ deficiency symptoms were observed.

It has been reported that the critical leaf $\mathrm{K}$ concentration affecting cotton yield was $8.5 \mathrm{~g} \cdot \mathrm{kg}^{-1}$ during peak flowering, whereas, [36] reported the critical concentration to be $15 \mathrm{~g} \cdot \mathrm{kg}^{-1}$. An experiment conducted in an indoor facility by [23] argued it to be 6.7 to $9.5 \mathrm{~g} \cdot \mathrm{kg}^{-1}$ during squaring which influences growth and physiology. This study clearly indicated the critical $\mathrm{K}$ level achieved to study its effects on growth, reproductive performance and fiber quality.

\subsection{Leaf Chlorophyll, Cell Membrane Thermostability and Gas Exchange Processes}

Leaf chlorophyll content expressed in $\mu \mathrm{g} \cdot \mathrm{cm}^{-2}$ significantly differed $(P=0.02$; Figure 2(a)) among $\mathrm{K}$ treatments in years, 2010 and 2011 . The 40 and $20 \mathrm{~K}$ treatment plants had comparable chlorophyll content to those of control plants, but the plants receiving $0 \mathrm{~K}$ had $14 \%$ and $16 \%$ lower chlorophyll in year 2010 and 2011, respectively (Figure 2(a)). This is because the $\mathrm{K}$ deficient plant leaves were filled with more starch granules and fewer grana as compared to K sufficient plants $[10]$ and disrupting the chloroplast. Similar results were recorded in a K-deficient maize experiment conducted by [37] working with soybean and by [38] in cotton, respectively.

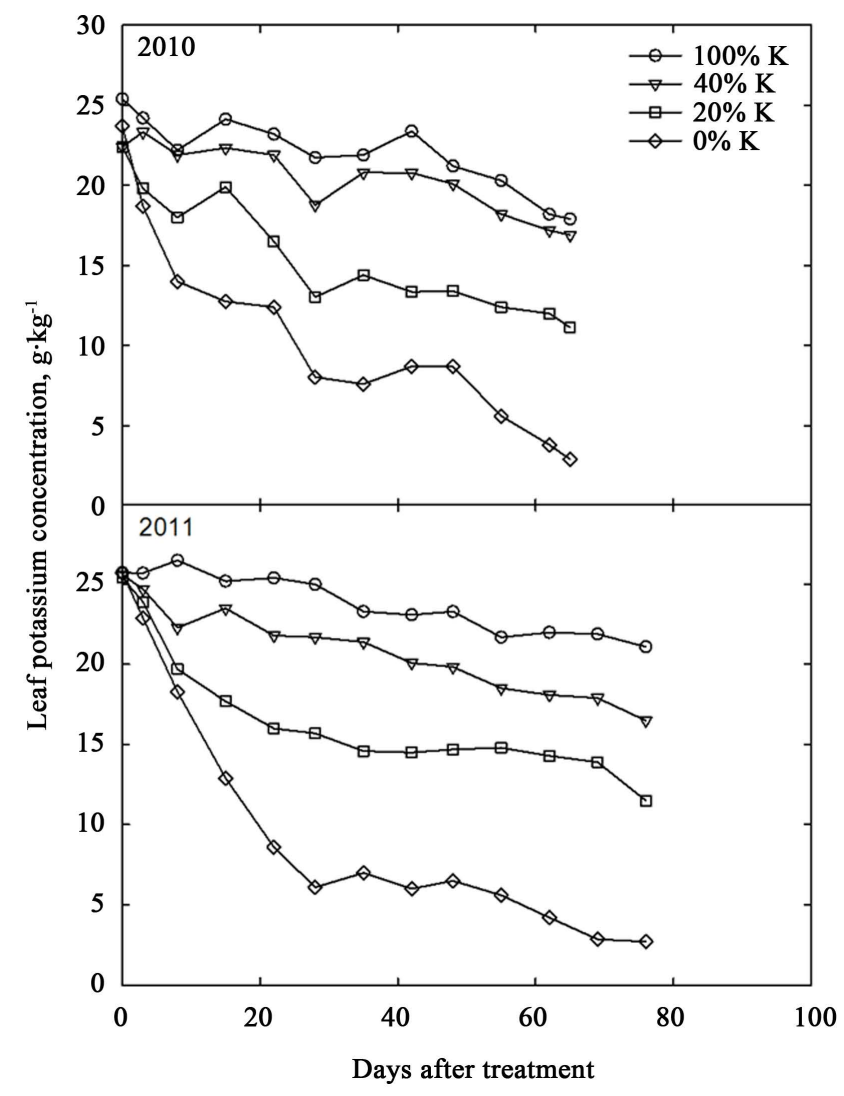

Figure 1. Temporal trends in average leaf potassium levels during the treatment period for four levels of $\mathrm{K}$ treatments, $100 \%, 40 \%, 20 \%$ and $0 \%$ of control, imposed during the reproductive period of cotton for the years 2010 and 2011. Each potassium level was represented by lines in curves. 


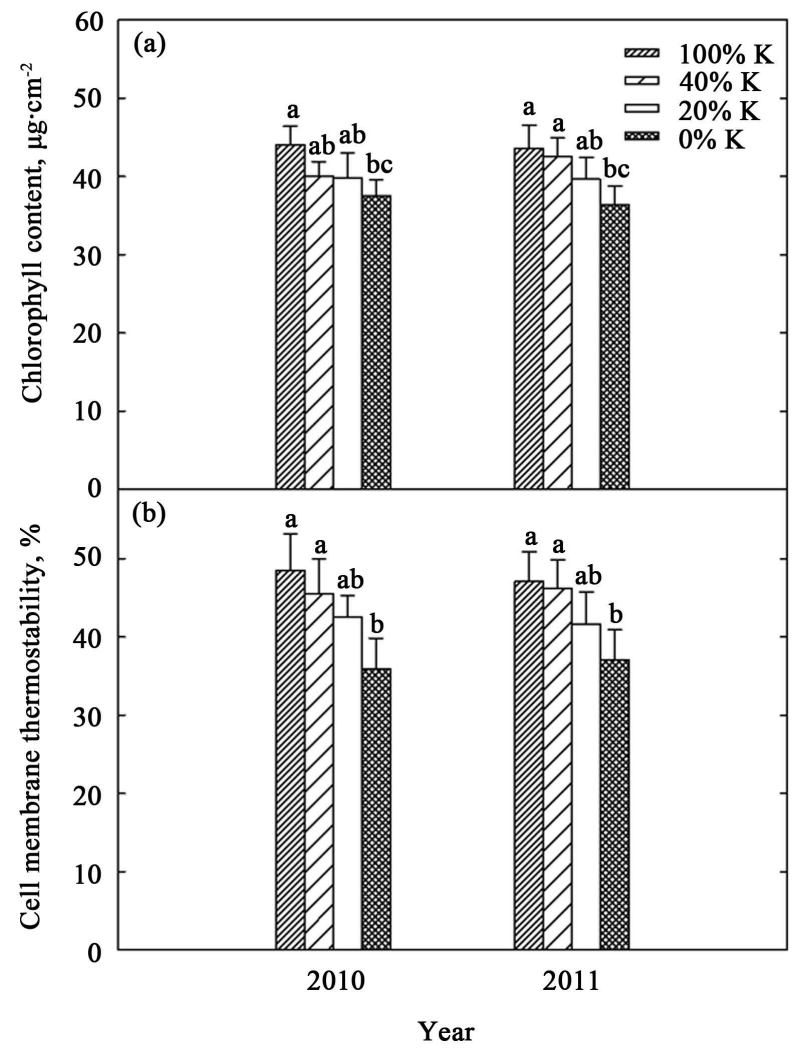

Figure 2. Potassium stress effects on cotton total chlorophyll content and cell membrane thermostability. Measurements were taken at 42 days after treatment on topmost fully expanded leaves from three plants and from each treatment. Error bars indicates $( \pm)$ standard error.

There were significant reductions of $25 \%$ and $21 \%$ in year 2010 and 2011, respectively, in cell membrane thermostability (CMTS) of potassium deficient plants $(0 \mathrm{~K})$ compared to control (Figure 2(b)). It has been suggested that osmotic potential in leaf tissues may influence CMTS because of the close relationship between water relations and nutrient concentrations in cell sap and leaf tissues [39]. Potassium acts as osmoticum to balance turgor pressure, therefore, $\mathrm{K}$ deficiency influences the relative water content of leaves and subsequently increases injury to the cell membranes.

Photosynthesis declined linearly $\left(r^{2}=0.84\right.$; Figure 3$)$ with decrease in leaf $\mathrm{K}$ content. Maximum photosynthesis of $32.8 \mu \mathrm{mol} \cdot \mathrm{m}^{-2} \cdot \mathrm{s}^{-1}$ was observed at $\mathrm{K}$ content of $25.7 \mathrm{~g} \cdot \mathrm{kg}^{-1}$, whereas, at $6 \mathrm{~g} \cdot \mathrm{kg}^{-1}$, a $28 \%$ decline in photosynthesis was recorded (Figure 3). The rate of decline in photosynthesis was $0.31 \mu \mathrm{mol} \cdot \mathrm{m}^{-2} \cdot \mathrm{s}^{-1}$ per unit decrease in leaf K content. Stomatal conductance also declined linearly $\left(r^{2}=0.80\right.$; Figure 3$)$ with decrease in leaf K content. However, stomatal conductance decline (slope $=0.015$; Figure 3 ) was less steep when compared to the decline (slope $=0.45$; Figure 3 ) observed in photosynthesis. Since there was essentially no change in internal carbon dioxide $(\mathrm{Ci})$ with decreased leaf $\mathrm{K}$ except at the very low leaf $\mathrm{K}$ levels, the decline in photosynthesis may be related decline in stomatal conductance. At the very low levels of leaf $\mathrm{K}$, the decline in photosynthesis may be due to both stomatal and non-stomatal limitations as it also affects chlorophyll [10] [40]. Our results are in agreement with prior reports of a close relationship between leaf $\mathrm{K}$ levels and chlorophyll [3] [10] and stomatal conductance [3] in other crops.

\subsection{Growth and Yield Attributes}

Knowledge of the manner in which potassium affects vegetative and reproductive growth is essential to understand $\mathrm{K}$ nutrition of cotton plants. Plant height increased as plants aged, but plants grown under different $\mathrm{K}$ treatments were shorter compared to optimum K treatments in both the years (Figure 4). The greatest decrease 


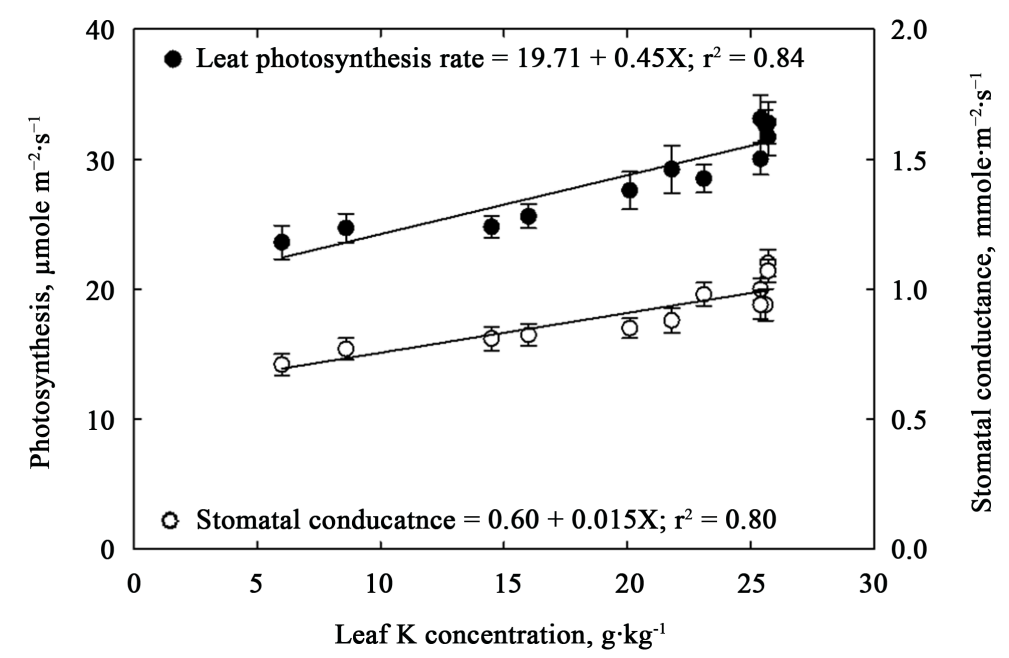

Figure 3. Relationship between cotton leaf potassium levels and leaf photosynthesis rate and stomatal conductance. Parameter was measured on topmost fully expanded leaf (from 0 to 56 days after treatment at an interval of seven days) with three samples per treatment by using Li-COR-6400 photosynthesis system with chamber $\mathrm{CO}_{2}$ concentration of $380 \mu \mathrm{mol} \cdot \mathrm{mol}^{-1}$, temperature of $30^{\circ} \mathrm{C}$ and photosynthetically active radiation of $1500 \mu \mathrm{mole} \cdot \mathrm{m}^{-2} \cdot \mathrm{s}^{-1}$. Measurements were taken from 10:00 a.m. to 1:30 p.m. in clear sky conditions.
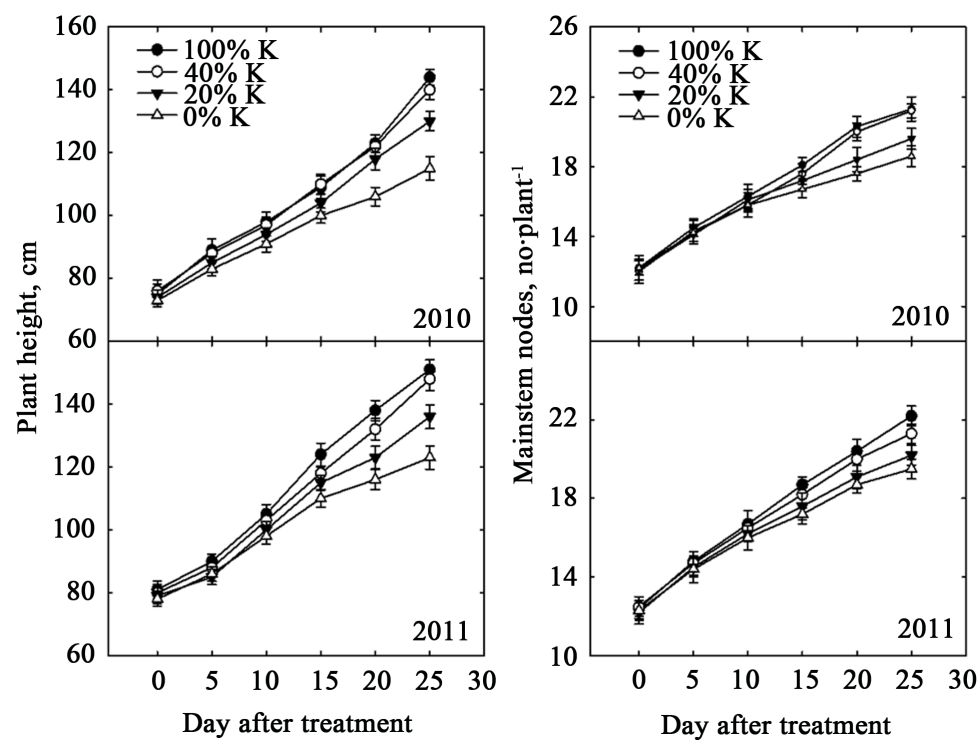

Figure 4. Influence of potassium treatments on cotton plant height and main stem nodes of cotton for year 2010 and 2011. Each data point is mean of nine individual plants and with standard errors.

in plant height was observed at the $0 \mathrm{~K}$ treatment compared to optimally-fed plants in both the years. After 25 days after treatment, plants grown under control $(100 \mathrm{~K})$ were $144 \mathrm{~cm}$ (year 2010) and $151 \mathrm{~cm}$ (year 2011). In comparison to the control, $\mathrm{K}$ treatments of 40,20 , and $0 \mathrm{~K}$, plant height decreased by $2 \%, 10 \%$, and $20 \%$ for year 2010 , and, $2 \%, 9 \%$, ad $19 \%$ for year 2011 , respectively. Similarly, adding nodes or leaves on the mainstem increased as plants aged in both years (Figure 4), but the rate of increase was much less in K-deficient treatments. In year 2010 and 2011, at 25 days after treatment, there was reduction of $13 \%$ and $12 \%$ in $\mathrm{K}$ deficient treatment $(0 \mathrm{~K})$, respectively, as compared to the control. Cotton plants require large amount of $\mathrm{K}$ for optimum growth and yield [16] [38] and potassium is an important constituent in transportation of photo-assimilates from 
leaves to other plant parts. Node addition rates are typically controlled by temperature, but modulated by demand/supply of carbohydrates. Therefore, declining $\mathrm{K}$ in the leaves and thus photosynthesis might have caused lower production mainstem nodes in cotton under K-deficient treatments [9].

Plants grown under potassium deficient conditions produced significantly lower biomass $(P<0.001)$ per plant. In year 2010 and 2011, control treatment plants produced 226 and $237 \mathrm{~g} \cdot$ plant $^{-1}$ of biomass, respectively, whereas in $0 \mathrm{~K}$ treatments, biomass production was reduced by $27 \%$ and $28 \%$, respectively, during the same years (Figure 5). Reduction in biomass may be due to reduced leaf area and $\mathrm{CO}_{2}$ assimilation rates [3] which subsequently restrict reproductive growth and development. The retained boll numbers per plant decreased $(P=$ 0.002; Figure 6) in plants grown under K deficient conditions. The control treatment retained 13 and 14 bolls per plant in year 2010 and 2011, respectively; however, only 9 and 10 bolls per plant were retained in the $0 \mathrm{~K}$ treatment during the same years (Figure 6). Several others reported similar declining trends under for boll numbers and plant dry weight [10] similar to our results which lead to fewer retained bolls. Seedcotton, lint, and seed weights per plant were not significantly affected by $\mathrm{K}$ treatment in the first and second flowering groups in both years, whereas in the third and fourth flowering group, the weights of those components were significantly lowered under $\mathrm{K}$ deficient plants (Table 1). In flowering group four, 20 and $0 \mathrm{~K}$ treatments resulted in significantly decreased seedcotton $(P=0.021$ and $P=0.013)$, lint $(P=0.01$ and $P=0.03)$ and seed weight $(P=0.02$ and $P=0.03$ ) per plant in year 2010 and 2011, respectively (Table 1). For $100 \mathrm{~K}, 56$ and $63 \mathrm{~g}$ per plant of total seedcotton was produced while a reduction of 25 and $30 \%$ compared to the control were recorded for $0 \mathrm{~N}$ in years 2010 and 2011, respectively (Table 1).

Table 1. Seedcotton, seed and lint weight per plant affected by K fertilization rates across years 2010 and 2011 cotton growing season.

\begin{tabular}{|c|c|c|c|c|c|c|c|c|c|c|}
\hline \multirow{2}{*}{$\begin{array}{l}\text { Potassium } \\
\text { treatment }\end{array}$} & \multicolumn{2}{|c|}{ Group 1} & \multicolumn{2}{|c|}{ Group 2} & \multicolumn{2}{|c|}{ Group 3} & \multicolumn{2}{|c|}{ Group 4} & \multicolumn{2}{|c|}{ Total } \\
\hline & $\begin{array}{c}2010 \\
\text { (2-8 July) }\end{array}$ & $\begin{array}{c}2011 \\
\text { (3-9 July) }\end{array}$ & $\begin{array}{c}2010 \\
\text { (9-15 July) }\end{array}$ & $\begin{array}{c}2011 \\
\text { (10-16 July) }\end{array}$ & $\begin{array}{c}2010 \\
\text { (16-22 July) }\end{array}$ & $\begin{array}{c}2011 \\
\text { (17-24 July) }\end{array}$ & $\begin{array}{c}2010 \\
\text { (23-30 July) }\end{array}$ & $\begin{array}{c}2011 \\
\text { (15-31 July) }\end{array}$ & 2010 & 2011 \\
\hline \multicolumn{11}{|c|}{ Seedcotton weight $\left(\mathrm{g} \cdot\right.$ plant $\left.^{-1}\right)$} \\
\hline Control & 16.1 & 17.0 & 15.3 & 17.6 & $13.3 \mathrm{a}$ & $15.2 \mathrm{a}$ & $11.6 \mathrm{a}$ & 13.0 & $56.3 \mathrm{a}$ & $62.8 \mathrm{a}$ \\
\hline $40 \% \mathrm{~K}$ & 14.9 & 15.7 & 14.8 & 17.4 & $12.0 \mathrm{a}$ & $13.9 \mathrm{a}$ & $9.3 \mathrm{a}$ & $10.4 \mathrm{a}$ & $51.0 \mathrm{a}$ & $57.5 \mathrm{a}$ \\
\hline $20 \% \mathrm{~K}$ & 15.6 & 15.9 & 14.3 & 15.4 & $10.8 \mathrm{ab}$ & $11.8 \mathrm{ab}$ & $4.9 \mathrm{~b}$ & $5.6 \mathrm{~b}$ & $45.5 b$ & $48.7 \mathrm{~b}$ \\
\hline $0 \% \mathrm{~K}$ & 15.5 & 15.1 & 13.3 & 14.6 & $9.3 \mathrm{bc}$ & $10.4 \mathrm{bc}$ & $4.0 \mathrm{~b}$ & $3.8 \mathrm{c}$ & $42.2 \mathrm{~b}$ & $43.9 \mathrm{~b}$ \\
\hline $\operatorname{LSD}(0.05)$ & ns & ns & ns & ns & 2.1 & 2.8 & 2.5 & 1.6 & 5.4 & 6.1 \\
\hline \multicolumn{11}{|c|}{ Lint weight $\left(\mathrm{g} \cdot\right.$ plant $\left.^{-1}\right)$} \\
\hline Control & 6.1 & 6.5 & 5.8 & 6.7 & $5.1 \mathrm{a}$ & $5.8 \mathrm{a}$ & $4.4 \mathrm{a}$ & $4.9 \mathrm{a}$ & $21.4 \mathrm{a}$ & $23.9 \mathrm{a}$ \\
\hline $40 \% \mathrm{~K}$ & 5.9 & 6.3 & 5.9 & 7.0 & $4.8 \mathrm{ab}$ & $5.6 \mathrm{ab}$ & $3.7 \mathrm{a}$ & $4.2 \mathrm{a}$ & $20.4 \mathrm{ab}$ & $23.0 \mathrm{ab}$ \\
\hline $20 \% \mathrm{~K}$ & 6.5 & 6.7 & 6.0 & 6.4 & $4.5 \mathrm{ab}$ & $5.0 \mathrm{ab}$ & $2.1 \mathrm{~b}$ & $2.4 \mathrm{~b}$ & $19.1 \mathrm{ab}$ & $20.5 \mathrm{ab}$ \\
\hline $0 \% \mathrm{~K}$ & 6.4 & 6.2 & 5.4 & 6.0 & $3.8 \mathrm{bc}$ & $4.3 \mathrm{bc}$ & $1.6 \mathrm{~b}$ & $1.6 \mathrm{c}$ & $17.3 b c$ & $18.0 \mathrm{bc}$ \\
\hline $\operatorname{LSD}(0.05)$ & ns & ns & $\mathrm{ns}$ & $\mathrm{ns}$ & 0.9 & 1.1 & 0.9 & 0.8 & 2.0 & 2.6 \\
\hline \multicolumn{11}{|c|}{ Seed weight $\left(g \cdot\right.$ plant $\left.^{-1}\right)$} \\
\hline Control & 10.0 & 10.5 & 9.5 & 10.9 & $8.2 \mathrm{a}$ & $9.4 \mathrm{a}$ & $7.2 \mathrm{a}$ & $8.1 \mathrm{a}$ & $34.8 \mathrm{a}$ & $38.9 \mathrm{a}$ \\
\hline $40 \% \mathrm{~K}$ & 8.9 & 9.4 & 8.9 & 10.4 & $7.2 \mathrm{ab}$ & $8.4 \mathrm{ab}$ & $5.6 \mathrm{a}$ & $6.3 \mathrm{a}$ & $30.5 \mathrm{ab}$ & $34.5 \mathrm{a}$ \\
\hline $20 \% \mathrm{~K}$ & 9.0 & 9.2 & 8.3 & 8.9 & $6.2 \mathrm{ab}$ & $6.8 \mathrm{ab}$ & $2.8 \mathrm{~b}$ & $3.3 b$ & $26.3 \mathrm{ab}$ & $28.3 b$ \\
\hline $0 \% \mathrm{~K}$ & 9.2 & 8.9 & 7.8 & 8.6 & $5.5 \mathrm{bc}$ & $6.2 \mathrm{bc}$ & $2.4 \mathrm{~b}$ & $2.3 b$ & $24.8 \mathrm{bc}$ & $25.9 b$ \\
\hline $\operatorname{LSD}(0.05)$ & ns & ns & $\mathrm{ns}$ & ns & 1.6 & 1.4 & 1.5 & 1.1 & 4.5 & 4.3 \\
\hline
\end{tabular}

Measurements were recorded at $80 \%$ of boll opening in each treatment. "Within columns, mean followed by same letter are not significantly different at 0.05 level of probability. ns: not significant. 


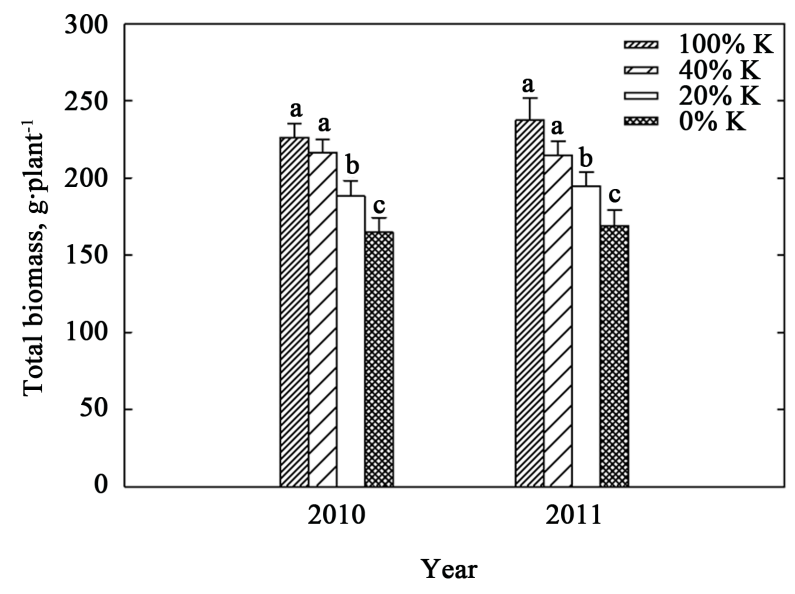

Figure 5. Potassium effects on total biomass production measured at the end of the experimental period during 2010 and 2011 growing season of cotton. Plants were harvested at $80 \%$ of boll opening in each treatment. Values represents mean of 24 plants in each treatment.

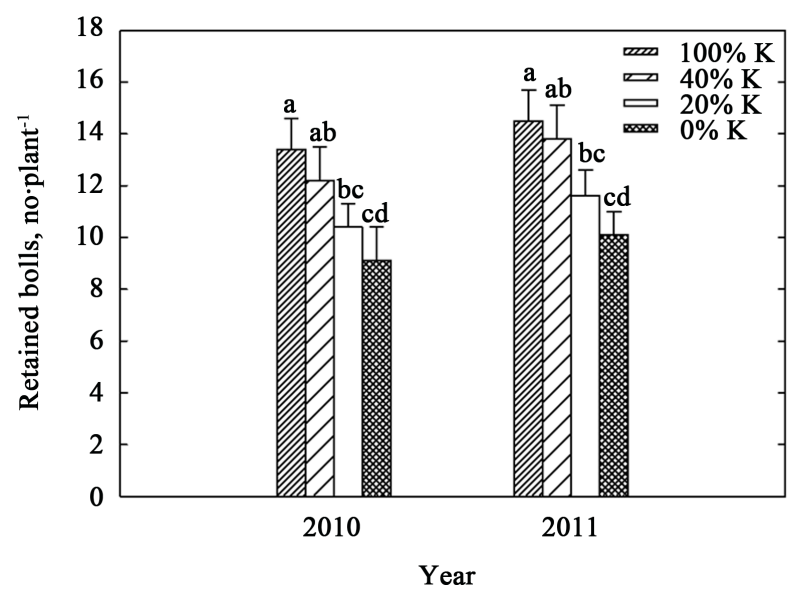

Figure 6. Potassium treatment, $100 \%, 40 \%, 20 \%$ and $0 \%$ of control, effects on retained bolls of cotton per plant. Plants were harvested at $80 \%$ of boll opening in each treatment. Values represents mean of 24 plants in each treatment.

In year 2010, lint and seed weight per plant were reduced by $19 \%$ and $28 \%$ in $0 \mathrm{~K}$ treatments, respectively; whereas, reductions of $24 \%$ and $33 \%$, respectively, were recorded in year 2011 (Table 1). The decrease in seedcotton weight was due to reduction in seed and lint weight per boll and retained bolls per plant [13]. By imposing the treatments a few days before flowering, potassium content started deplete gradually in the cotton plants (Figure 1). Therefore, the bolls that were developed in later stages of fruiting period showed significant reduction in boll numbers and individual boll weights similar to the results observed by Reed et al. [13]. This might be due to lowered assimilate production, reduction in leaf area and slower rates assimilate translocation under K-deficit treatments as observed in other studies [3].

\subsection{Fiber Quality Parameters}

This study determined the fiber quality trends with respect to leaf $\mathrm{K}$ averaged over the boll maturation period starting from anthesis. Fiber quality is mainly determined by fiber cell elongation, primary and secondary cell wall deposition and maturation. It will be reasonable to use leaf $\mathrm{K}$ concentration to evaluate the effect of $\mathrm{K}$ nutrition on fiber quality [41]. 
Fiber length declined linearly with leaf $\mathrm{K}$ concentration $\left(r^{2}=0.49\right.$; Figure 7(a)), and the longest fibers (28.9 $\mathrm{mm}$ ) were recorded at optimum potassium $\left(25 \mathrm{~g} \cdot \mathrm{kg}^{-1}\right)$ levels. The decline in fiber length was $0.03 \mathrm{~mm}$ per unit of leaf K content. In spite of this decrease in fiber length, the recorded values are within the range of 24 to 28 $\mathrm{mm}$, which is acceptable for mills [14]. Although, fiber uniformity decreased linearly $\left(r^{2}=0.29\right.$; Figure $\left.7(\mathbf{c})\right)$ with decrease in leaf potassium content, the changes in the uniformity were not significant and the uniformity remained within the range that is not penalized by mill industry ( $83 \%$ to $85 \%)$ [42].

The elongation period in the fiber development process is critical for fiber length [43] and potassium plays an imporatant role in uptake of sucrose in the plasma membrane during the elongation period [42]. Our results corroborate the findings of Reed et al. [13] who showed decreasing fiber length with declining leaf $\mathrm{K}$ levels in a pot-culture experiment. Although there is a significant decline in fiber length with increase in K deficiency, the uniformity was not significantly affected. This is because very few bolls were retained in the later part of K-deficient treatments in this study. These results are in accordance with those reported by [2] [18] that fiber uniformity ratio remained unaffected under $\mathrm{K}$ stress treatments.

Similar to length fiber strength also declined $\left(r^{2}=0.45\right.$; Figure $\left.7(b)\right)$ with decrease in leaf K. Plants grown under optimum $\mathrm{K}$ levels $\left(25 \mathrm{~g} \cdot \mathrm{kg}^{-1}\right)$ produced fibers with values of $30.0 \mathrm{~g} \cdot \mathrm{tex}^{-1}$, and these values declined to $28.3 \mathrm{~g} \cdot \mathrm{tex}^{-1}$, when leaf $\mathrm{K}$ levels declined to $4.6 \mathrm{~g} \cdot \mathrm{kg}^{-1}$. The lower values recorded in this study under lower levels of leaf $\mathrm{K}$ contents (26 to $29 \mathrm{~g} \cdot \mathrm{tex}^{-1}$ ) are in the medium strength fiber required for mills [44]. A field experiment conducted by [18] found a reduction in fiber strength at $0 \% \mathrm{~K}$ treatment corroborates our results.

Fiber micronaire readings as measured with the HVI instrument, similar to other fiber properties, declined with as leak levels during fiber development declined $\left(r^{2}=0.60\right.$; Figure $\left.7(\mathrm{~d})\right)$. The micronaire readings of 3.48 (discount range) were reported at leaf $\mathrm{K}$ concentration of $4.6 \mathrm{~g} \cdot \mathrm{kg}^{-1}$. The acceptable Upland cotton micronaire premium range was between 3.7 and 4.2, while base ranges were between 4.3 and 4.9. Micronaire values below 3.5 and above 4.9 will be penalized at the mill and would result in a price penalty [14]. Since micronaire is a measure of fiber maturity and fineness as an indirect measurement of air permeability [45], the the recoded values in the discount range may be the result of $\mathrm{K}$ involvement on photosynthesis and susequent transport to the seed and fibers during the development [44]. Typically, there will be a shift starting around 24 days after
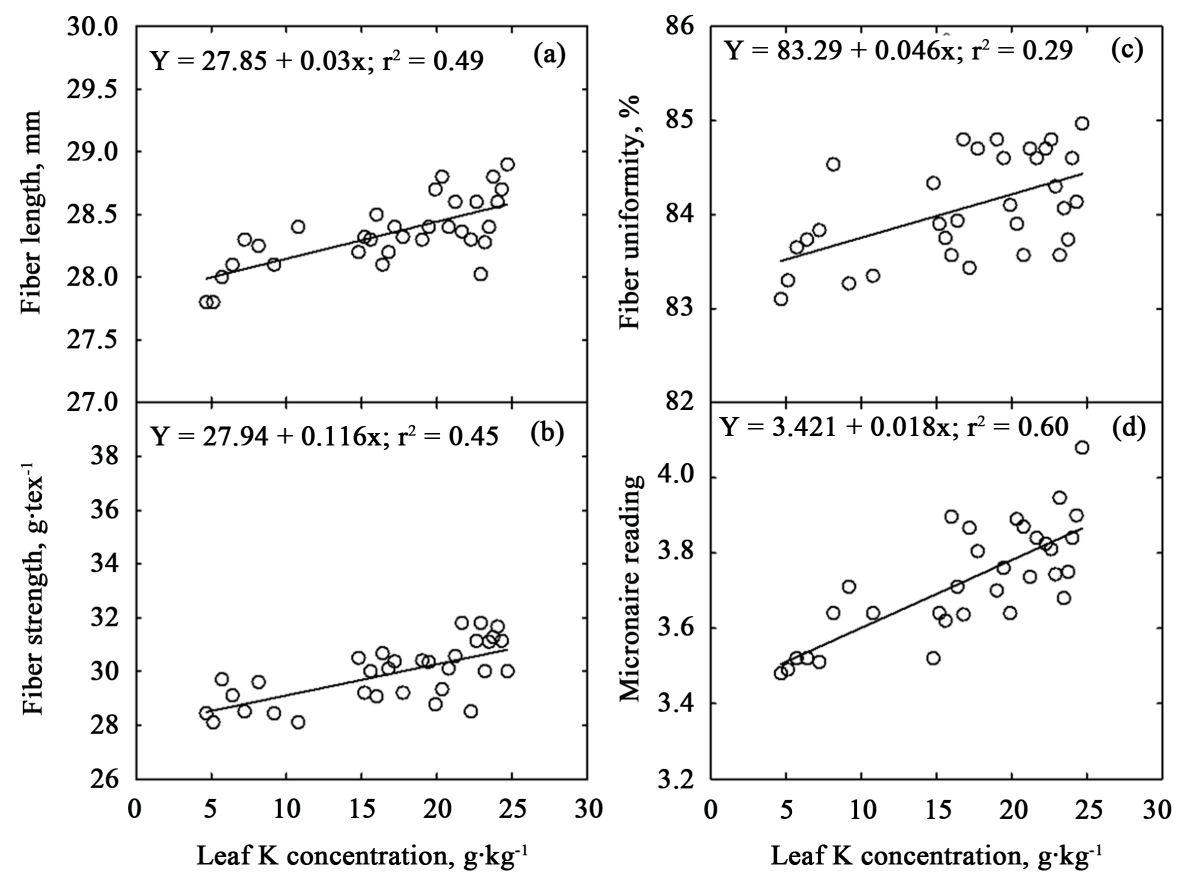

Figure 7. Relationships between cotton leaf K levels and fiber (a) length; (b) strength; (c) uniformity; (d) micronaire during the 2011 growing season. The K levels were averaged from flowering to boll opening, estimated by fitting regression analysis to estimate daily values. Cotton lint samples for fiber analysis was collected at the final harvest when $80 \%$ of boll opening in the treatments. 
anthesis is considered to be stage shift for sucrose metabolism in cotton fiber [46]. Potassium is involved in photosynthesis as it plays role plant water relations through the regulation of stomatal conductance and through carbohydrate transport related to translocation capacity of photosynthate and carbohydrates to bolls [9]. Prior studies showed that there is direct correlation between the amount of canopy photosynthesis and fiber micronaire values measured between 15 and 45 days of anthesis [25]. Therefore, potassium levels during fiber development plays critical role in defining the fiber micronaire in cotton.

\section{Conclusion}

This study evaluated cotton reproductive performance and fiber properties in relation to changes in potassium levels in the leaves. Our results showed that potassium deficiency caused a reduction mainstem length, node numbers, and total plant biomass, particularly at the lower levels. Retained bolls and boll components of cotton were substantially decreased in plants grown under limited $\mathrm{K}$ conditions. The primary gas exchange processes such as leaf photosynthesis and stomatal conductance declined significantly under potassium deficiency. Photosynthesis was more responsive to changes in cotton leaf $\mathrm{K}$ levels than stomatal conductance. However, decline in photosynthesis might be due to reduction in stomatal conductance, since internal carbon dioxide concentrations were unchanged under K-deficient conditions. Lower levels of $\mathrm{K}$ resulted in shorter and weaker fiber strengths. Fiber micronaire values fell into the discount range $(<3.5)$ under $\mathrm{K}$ deficit conditions. Changes in leaf $\mathrm{K}$, however, did not significantly affect fiber uniformity. The identified plant leaf $\mathrm{K}$ status-specific fiber functional relationships should be helpful to assist management practices during cotton growing season. Also, leaf $\mathrm{K}$-specific indices for fiber properties should be useful for developing sub-models for cotton fiber development and can be incorporated into cotton simulation models [47] to improve management practices under present and future climatic conditions. However, potential temperatures-specific fiber quality indices under optimum water and nutrient conditions [31] [48], nitrogen-specific [49] indices under optimum water and temperature conditions, and water deficit-specific [50] indices under optimum nutrient and temperature conditions are needed to develop a fiber model for cotton. Models equipped with fiber quality would be useful not only in production optimization of natural resources such as water and nutrients, but also in assisting planting dates in the current environment and in policy decisions for the hypothesized changes in future climate [51].

\section{Acknowledgements}

This research was in part funded by the Colorado State University USDA-UVB Monitoring and Research Program, Natural Resource Ecology Laboratory, Department of Ecosystem Science \& Sustainability, USDA-NIFA2011-34263-30654, G-1405-2. We also thank Mr. David Brand for technical support. This article is a contribution from the Department of Plant and Soil Sciences, Mississippi State University, Mississippi Agricultural and Forestry Experiment Station, paper no. J12607.

\section{References}

[1] Morrow, M.R. and Krieg, D.R. (1990) Cotton Management Strategies for a Short Growing Season Environment: Water-Nitrogen Considerations. Agronomy Journal, 82, 52-56. http://dx.doi.org/10.2134/agronj1990.00021962008200010011x

[2] Pettigrew, W.T. (2003) Relationships between Insufficient Potassium and Crop Maturity in Cotton. Agronomy Journal, 95, 1323-1329. http://dx.doi.org/10.2134/agronj2003.1323

[3] Reddy, K.R. and Zhao, D. (2005) Interactive Effects of Elevated $\mathrm{CO}_{2}$ and Potassium Deficiency on Photosynthesis, Growth, and Biomass Partitioning of Cotton. Field Crops Research, 94, 201-213. http://dx.doi.org/10.1016/j.fcr.2005.01.004

[4] Bo, L., Ye, W., Zhyong, Z., Baoming, W., Egrinya, E., Liusheng, D., Zhaohu, L. and Xiao, L. (2012) Cotton Shoot Play a Major Role in Mediating Senescence Induced by Potassium Deficiency. Journal of Plant Physiology, 169, 327335. http://dx.doi.org/10.1016/i.jplph.2011.10.009

[5] Humble, G.D. and Raschke, K. (1971) Stomatal Opening Quantitatively Related to Potassium Transport. Plant Physiology, 48, 447-453. http://dx.doi.org/10.1104/pp.48.4.447

[6] Evans, H.J. and Sorger, G.J. (1966) Role of Mineral Elements with Emphasis on the Univalent Cations. Annual Review of Plant Physiology, 17, 47-77. http://dx.doi.org/10.1146/annurev.pp.17.060166.000403

[7] Bednarz, C.W., Oosterhuis, D.M. and Evans, R.D. (1998) Leaf Photosynthesis and Carbon Isotope Discrimination of 
Cotton in Response to Potassium Deficiency. Environmental and Experimental Botany, 39, 131-139. http://dx.doi.org/10.1016/S0098-8472(97)00039-7

[8] Jiang, C.C., Xia, Y., Chen, F., Lu, J.W. and Wang, Y.H. (2011) Plant Growth, Yield Components, Economic Responses and Soil Indigenous K Uptake of Two Cotton Genotypes with Different K Efficiency. Agricultural Sciences in China, 5, 705-713. http://dx.doi.org/10.1016/S1671-2927(11)60053-9

[9] Pettigrew, W.T. and Meredith, W.R. (1997) Dry Matter Production, Nutrient Uptake, and Growth of Cotton as Affected by Potassium Fertilization. Journal of Plant Nutrition, 20, 531-548. http://dx.doi.org/10.1080/01904169709365272

[10] Zhao, D., Oosterhuis, D.M. and Bednarz, C.W. (2001) Influence of Potassium Deficiency on Photosynthesis, Chlorophyll Content, and Chloroplast Ultrastructure of Cotton Plants. Photosynthetica, 39, 103-109. http://dx.doi.org/10.1023/A:1012404204910

[11] Raschke, K. (1975) Stomatal Action. Annual Review of Plant Physiology, 26, 309-340. Reddy, K.R., Hodges, H.G. and Reddy, V.R. (1992) Temperature Effects on Cotton Fruit Retention. Agronomy Journal, 84, 26-30.

[12] Boquet, D.J. and Breitenbeck, G.A. (2000) Nitrogen Rate Effect on Partitioning of Nitrogen and Dry Matter by Cotton. Crop Science, 40, 1685-1693. http://dx.doi.org/10.2135/cropsci2000.4061685x

[13] Read, J.J., Reddy, K.R. and Jenkins, J.N. (2006) Yield and Fiber Quality of Upland Cotton as Influenced by Nitrogen and Potassium Nutrition. European Journal of Agronomy, 24, 282-290. http://dx.doi.org/10.1016/j.eja.2005.10.004

[14] Bradow, J.M. and Davidonis, G.H. (2000) Quantitation of Fiber Quality and the Cotton Production-Processing Interface: A Physiologist's Perspective. Journal of Cotton Science, 4, 34-64.

[15] Pettigrew, W.T. (1999) Potassium Deficiency Increase Specific Leaf Weights and Leaf Glucose Levels in Field-Grown Cotton. Agronomy Journal, 91, 962-968. http://dx.doi.org/10.2134/agronj1999.916962x

[16] Kerby, T.A. and Adams, F. (1985) Potassium Nutrition of Cotton. In: Munson, R.D., Ed., Potassium in Agriculture, American Society of Agronomy, Madison, 843-860.

[17] Reddy, K.R., Hodges, H.F. and Varco, J. (2000) Potassium Nutrition of Cotton. Bulletin, Office of Agriculture Communication, Mississippi State University, Division of Agriculture, Forestry and Veternary Medicine, No 1054, 1-10.

[18] Gormus, O. and Yucel, C. (2002) Different Planting Date and Potassium Fertility Effects on Cotton Yield and Fiber Properties in the Cukurova Region, Turkey. Field Crops Research, 78, 141-149. http://dx.doi.org/10.1016/S0378-4290(02)00121-1

[19] Boquet, D.J. and Moser, E.B. (2003) Boll Retention and Boll Size among Intrasympodial Fruiting Sites in Cotton. Crop Science, 43, 195-201. http://dx.doi.org/10.2135/cropsci2003.1950

[20] Mullins, G.L. and Burmester, C.H. (1990) Dry Matter, Nitrogen, Phosphorus, and Potassium Accumulation by Four Cotton Varieties. Agronomy Journal, 82, 729-736. http://dx.doi.org/10.2134/agronj1990.00021962008200040017x

[21] Davidonis, G.H., Johnson, A.S., Landivar, J.A. and Fernandez, C.J. (2004) Cotton Fiber Quality Is Related to Boll Location and Planting Date. Agronomy Journal, 96, 42-47. http://dx.doi.org/10.2134/agronj2004.0042

[22] Ramey, J. and Harmon, H. (1986) Stress Influences on Fiber Development. In: Mauney, J.R. and Stewart, J.M., Eds., Cotton Physiology, The Cotton Foundation, Memphis, TN, 351-359.

[23] Pettigrew, W.T., Heitholt, J.J. and Meredith, W.R. (1996) Genotypic Interactions with Potassium and Nitrogen in Cotton of Varied Maturity. Agronomy Journal, 88, 89-93. http://dx.doi.org/10.2134/agronj1996.00021962008800010019x

[24] Deussen, H. (1986) Stressing High Strength, Low Micronaire May Require Are Thinking of Breeding and Marketing Methods. In: Spencer, W., Ed., Cotton International, 53rd Edition, Meister Publishing Co., Memphis, TN, 32-36.

[25] Bauer, P.J., Frederick, J.R., Bradow, J.M., Sadler, E.J. and Evans, D.E. (2000) Canopy Photosynthesis and Fiber Properties of Normal- and Late-Planted Cotton. Agronomy Journal, 92, 518-523. http://dx.doi.org/10.2134/agronj2000.923518x

[26] Pettigrew, W.T. (2003) Relationships between Insufficient Potassium and Crop Maturity in Cotton. Agronomy Journal, 95, 1323-1329. http://dx.doi.org/10.2134/agronj2003.1323

[27] Minton, E.B. and Ebelhar, M.W. (1991) Potassium and Aldicarb-Disulfoton Effects on Verticillium Wilt, Yield, and Quality of Cotton. Crop Science, 31, 209-212. http://dx.doi.org/10.2135/cropsci1991.0011183X003100010046x

[28] Hewitt, E.J. (1952) Sand and Water Culture: Methods Used in the Study of Plant Nutrition. Technical Communication No. 22, Commonwealth Bureau of Horticulture and Plantation, East Malling. Kent Publishers, Commonwealth Agricultural Bureaux Farmham Royal, Bucks, England, 187-190.

[29] Stelly, D.M., Saha, S., Raska, D.A., Jenkins, J.N., McCarty, J.C. and Gutierrez, O.A. (2005) Registration of 17 Upland (Gossypium hirsutum) Cotton Germplasm Lines Disomic for Different G. barbadense Chromosome or Arm Substitutions. Crop Science, 45, 2663-2665. http://dx.doi.org/10.2135/cropsci2004.0642 
[30] Donohue, S.J. and Aho, D.W. (1992) Determination of P, K, Ca, Mg, Mn, Fe, Al, B, Cu, and Zn in Plant Tissue by Inductively Coupled Plasma (ICP) Emotion Spectroscopy. In: Plank, C.O., Ed., Plant Analysis Reference Procedures for the Southern Region of the United States, Southern Cooperative Series Bulletin 368, Georgia Agricultural Experimental Station, Athens, GA, 37-40.

[31] Reddy, K.R., Davidonis, G.H., Johnson, A.S. and Vinyard, B.T. (1999) Temperature Regime and Carbon Dioxide Enrichment Alter Cotton Boll Development and Fiber Properties. Agronomy Journal, 91, 851-858. http://dx.doi.org/10.2134/agronj1999.915851x

[32] Chapple, C.S., Vogt, T., Ellis, B.E. and Somerville, C.R. (1992) An Arabidopsis Mutant Defective in the General Phenylpropanoid Pathway. The Plant Cell, 4, 1413-1424. http://dx.doi.org/10.1105/tpc.4.11.1413

[33] Martineau, J.R., Williams, J.H. and Specht, J.E. (1979) Temperature Tolerance in Soybeans. II. Evaluation of Segregating Populations for Membrane Thermostability. Crop Science, 19, 79-81. http://dx.doi.org/10.2135/cropsci1979.0011183X001900010018x

[34] Davidonis, G. and Hinojosa, O. (1994) Influence of Seed Location on Cotton Fiber Development in Planta and in Vitro. Plant Science, 103, 107-113. http://dx.doi.org/10.1016/0168-9452(94)03967-4

[35] SAS Institute (2011) SAS Guide to Macro Processing. Vol. 11, SAS Institute, Cary.

[36] Pettiet, J.V. (1994) Calibration of the Mehlich 3 Soil Test for Potassium Using Leaf Analyses and Potassium Deficiency Symptoms in Cotton Plants. Communications in Soil Science and Plant Analysis, 25, 3115-3127. http://dx.doi.org/10.1080/00103629409369252

[37] Hall, J.D., Barr, R., Al-Abbas, A.H. and Crane, F.L. (1972) The Ultrastructure of Chloroplasts in Mineral-Deficient Maize Leaves. Plant Physiology, 50, 404-409. http://dx.doi.org/10.1104/pp.50.3.404

[38] Oosterhuis, D.M. (1995) Potassium Nutrition of Cotton in the USA with Particular Reference to Foliar Fertilization. In: Constable, C.A. and Forrester, N.W., Eds., Proceedings First World Cotton Research Conference, CSIRO, Brisbane, 133-146.

[39] Premachandra, G.S., Saneoka, H. and Ogata, S. (1990) Cell Membrane Stability, an Indicator of Drought Tolerance as Affected by Applied Nitrogen in Soybean. Journal of Agricultural Science, 115, 63-66. http://dx.doi.org/10.1017/S0021859600073925

[40] Cakmak, I. (2005) The Role of Potassium in Alleviating Detrimental Effects of Abiotic Stresses in Plants. Journal of Plant Nutrition and Soil Science, 168, 521-530. http://dx.doi.org/10.1002/jpln.200420485

[41] Cassman, K.G., Kerby, T.A., Roberts, B.A., Bryant, D.C. and Higashi, S.L. (1990) Potassium Nutrition Effects on Lint Yield and Fiber Quality of Acala Cotton. Crop Science, 30, 672-677. http://dx.doi.org/10.2135/cropsci1990.0011183X003000030039x

[42] Ruan, Y.L., Llewellyn, D.J., Furbank, R.T. and Chourey, P.S. (2005) The Delayed Initiation and Slow Elongation of Fuzz-Like Short Fibre Cells in Relation to Altered Patterns of Sucrose Synthase Expression and Plasmodesmata Gating in a Lintless Mutant of Cotton. Journal of Experimental Botany, 56, 977-984. http://dx.doi.org/10.1093/jxb/eri091

[43] Braden, C.A. and Smith, C.W. (2004) Fiber Length Development in Near-Long Staple Upland Cotton. Crop Science, 44, 1553-1559. http://dx.doi.org/10.2135/cropsci2004.1553

[44] Schleth, A.P. and Peter, G.A. (2005) USTER@ AFIS PRO, Application Handbook: Single Fiber Testing of Cotton. Uster Technologies AG, Wilstrasse 11, Uster, Switzerland..

[45] Moore, J.F. (1996) Cotton Classification and Quality. In: Glade, E.H., Meyer, L.A. and Stults, H., Eds., Cotton Industry in the United States, USDA-ERS Agricultural Economic Report 739, U.S. Government Printing Office Office, Washington DC, 51-57.

[46] Ma, R.H., Xu, N.Y., Zhang, C.X., Li, W.F., Feng, Y., Qu, L., Wang, Y.H. and Zhou, Z.G. (2008) Physiological Mechanism of Sucrose Metabolism in Cotton Fiber and Fiber Strength Regulated by Nitrogen. Acta Agronomica Sinica, 34, 2143-2151. http://dx.doi.org/10.1016/S1875-2780(09)60023-7

[47] Thorp, K.R., Ale, S., Bange, M.P., Barnes, E.M., Hoogenboom, G., Lascano, R.J., McCarthy, A.C., Nair, S., Paz, J.O., Rajan, N., Reddy, K.R., Wall, G.W. and White, J.W. (2014) Development and Application of Process-Based Simulation Models for Cotton Production: A Review of Past, Present, and Future Directions. Journal of Cotton Science, 18, $10-47$.

[48] Lokhande, S. and Reddy, K.R. (2014) Quantifying Temperature Effects on Cotton Reproductive Efficiency and Fiber Quality. Agronomy Journal, 106, 1060-1069.

[49] Lokhande, S. and Reddy, K.R. (2015) Cotton Reproductive and Fiber Quality Responses to Nitrogen Nutrition. International Journal of Plant Production, 9, 191-209.

[50] Lokhande, S. and Reddy, K.R. (2014) Reproductive and Fiber Quality Responses of Upland Cotton to Moisture Deficiency. Agronomy Journal, 106, 1060-1069. http://dx.doi.org/10.2134/agronj13.0537 
[51] Liang, X.Z., Xu, M., Gao, W., Reddy, K.R., Kunkel, K., Schmoldt, D.L. and Samel, A.N. (2012) Physical Modeling of U.S. Cotton Yields and Climate Stresses during 1979 to 2005. Agronomy Journal, 104, 675-683. http://dx.doi.org/10.2134/agronj2011.0251 